Najmuddin Khairur Rijal, Siti Malikatul Mushowwiroh | Dinamika Hubungan Sipil-

Militer di Zimbabwe: dari Pra-Merdeka hingga

Lengsernya Robert Mugabe

Article

\title{
Dinamika Hubungan Sipil-Militer di Zimbabwe: dari Pra-Merdeka hingga Lengsernya Robert Mugabe
}

Najmuddin Khairur Rijal ${ }^{1}$, Siti Malikatul Mushowwiroh ${ }^{2}$
${ }^{1}$ International Relation Department, Universitas Negeri Malang, Indonesia.
${ }^{2}$ International Relation Department, Universitas Negeri Malang, Indonesia

\section{SUBMISSION TRACK}

$\begin{array}{ll}\text { Recieved } & : 29, \text { March } 2018 \\ \text { Final Revision } & : 07, \text { Sept } 2018 \\ \text { Available Online } & : \text { 30 Nov } 2018\end{array}$

KEYWORD

Civil-Military Relations, Zimbabwe, Robert

Mugabe, military

\section{KATA KUNCI}

Hubungan Sipil-Militer, Zimbabwe, Robert Mugabe, militer

\section{CORRENPONDENCE}

Phone : 085255637010

Email : najamuddin@umm.ac.id

\section{A B S T R A C T}

This paper study about the dynamics of the civil-military relations in Zimbabwe's politics. That civil-military relations dynamics tracked since the pre-independence until 2017 at the impeachment of 37 years Robert Mugabe's power. Two models of civil-military relations according to Huntington, i.e., the subjective and objective civil-military relations is used to analyze the pattern of relationships that formed during the reign of Mugabe. This paper is a descriptive study with data collection through the study documentation. The results indicate that civil-military relations in Zimbabwe take place dynamically. The early reign of Mugabe puts the military on their professionalism. However, in the next, the military used as a political tool to retain power making the pattern of civil-military relations become subjective control. Next, constitutional amendment sought to encourage the military to apolitical even though at the end back into the subjective control before finally shedding its support on Mugabe to keep his interests.

\section{A B S T R A K}

Tulisan ini membahas mengenai dinamika hubungan sipilmiliter dalam politik di Zimbabwe. Dinamika hubungan sipil-militer tersebut dilacak sejak era pra kemerdekaan hingga lengsernya Robert Mugabe pada 2017 yang berkuasa selama 37 tahun. Dua model hubungan sipil-militer menurut Huntington, yakni hubungan sipil-militer subjektif dan objektif digunakan untuk melihat pola relasi yang terbentuk selama kekuasaan Mugabe. Tulisan ini merupakan jenis penelitian deskriptif dengan pengumpulan data melalui studi dokumentasi. Hasil kajian ini menunjukkan bahwa hubungan sipil-militer di Zimbabwe berlangsung dinamis. Awal pemerintahan Mugabe menempatkan militer pada profesionalismenya. Namun, dalam perjalanannya, militer digunakan sebagai alat politik untuk mempertahankan kekuasaan sehingga menjadikan pola hubungan sipil-militer menjadi kontrol subjektif. Selanjutnya, amandemen konstitusi mendorong militer untuk apolitis meskipun pada akhirnya kembali menjadi kontrol subjektif sebelum akhirnya menanggalkan dukungannya pada Mugabe untuk tetap menjaga kepentingannya. 


\section{Pendahuluan}

Tulisan ini berusaha melacak perjalanan historis dinamika pola hubungan sipil-militer dalam politik Zimbabwe. Pelacakan perjalanan historis itu dimulai dari masa perjuangan kemerdekaan hingga lengsernya Robert Mugabe. Robert Mugabe sendiri adalah Presiden Zimbabwe yang berkuasa sejak kemerdekaan negaranya dari Inggris pada tahun 1980. Eksistensi kekuasaannya mampu bertahan selama 37 tahun hingga 2017. Keberhasilan mempertahankan kekuasaan selama hampir empat dekade itu tidak dapat dilepaskan oleh dukungan kekuatan militer.

Kekuasaan otoriter di mana pun, dalam sejarahnya, selalu ditopang oleh eksistensi kekuatan militer. Karena itu, Samuel Huntington menyatakan bahwa jatuhnya rezim otoriter sangat bergantung pada sejauhmana militer menarik dukungannya terhadap rezim. ${ }^{1}$ Artinya, durasi eksistensi otoritarianisme akan sangat ditentukan oleh sikap, posisi, dan kontribusi militer pada rezim tersebut. Hal itulah yang terjadi pada Mugabe.

Selama 37 tahun kepemimpinan Mugabe, militer tidak jarang diarahkan untuk melakukan sebuah konspirasi guna mencapai kepentingannya dalam mempertahankan kekuasaan, baik dengan memboikot pemilu, maupun mengontrol masyarakat untuk tidak melakukan perlawanan terhadap aturan yang ditetapkan. Baik Mugabe maupun militer bersifat saling bergantung sehingga kekuatan militer dan otoritas eksekutif seolah menjadi kombinasi dalam mengeksploitasi negara. Meski militer tidak terlibat secara langsung dalam day to day politics Zimbabwe, namun dalam setiap kebijakan maupun keputusan Mugabe, kedudukan dan kepentingan militer tidak dapat dikesampingkan sehingga berimplikasi pada pembentukan skema peran militer yang dipolitisasi. ${ }^{2}$

1 Samuel P. Huntington, Gelombang Demokratisasi Ketiga (Jakarta: Pustaka Utama Grafiti, 1995), 190.

2 Godfrey Maringira dan Tyanai Masiya, "Implications of a Politicised Military," Zimbabwe Independent, 11 Desember 2017, https://www.theindependent.co.zw/2017/12/11/im plications-politicised-military/ (diakses 15 Desember 2017).
Akan tetapi, pada 14 November 2017, terjadi gejolak politik yang menandai era baru dalam politik Zimbabwe. Angkatan Pertahanan Zimbabwe (Zimbabwe Defence Force/ZDF) melakukan sebuah operasi untuk mengambil alih daerah-daerah penting di ibukota Harare, menempatkan tank dan kendaraan militer di jalan, menyita siaran umum dan surat kabar, menduduki tempat tinggal Presiden, hingga menahan sejumlah Menteri Kabinet dan pejabat lainnya. Meski militer membantah untuk disebut melakukan kudeta, namun tindakan tersebut dilihat sebagai upaya melengserkan Mugabe. ${ }^{3}$

Krisis politik kemudian pecah. Masyarakat Zimbabwe menuntut mundurnya Mugabe. Para politisi di parlemen membicarakan upaya dan proses pemakzulan presiden berusia 93 tahun tersebut. Puncaknya pada 21 November 2017, hari ketika parlemen Zimbabwe memulai proses pemakzulannya, Mugabe melayangkan surat pengunduran diri dan meminta agar transisi kekuasaan berlangsung secara damai dan tanpa kekerasan.

"Saya, Robert Mugabe... dengan ini menyatakan pengunduran diri saya ... dengan cepat. Keputusan untuk mengundurkan diri ini saya lakukan secara sukarela dan muncul dari keprihatinan saya atas kesejahteraan rakyat Zimbabwe, serta keinginan saya untuk memastikan peralihan kekuasaan yang mulus, damai, dan tanpa kekerasan sehingga mewujudkan keamanan nasional, perdamaian, dan stabilitas... Mohon untuk memberi pemberitahuan ini kepada publik atas pengunduran diri saya sesegera mungkin, seperti yang ditulis dalam Pasal 96, Sub-Bab 1 Konstitusi Zimbabwe. Salam

\footnotetext{
${ }^{3}$ Adam Taylor, "Zimbabwe : When A Coup Is Not A Coup?," The Washington Post, https://www.washingtonpost.com/news/worldvie ws/wp/2017/11/15/zimbabwe-when-a-coup-isnot-a-coup/?utm_term=.c07cf8316f4a, (diakses 12 Desember 2017).
} 
sejahtera, Robert Gabriel Mugabe, Presiden Republik Zimbabwe."“4

Demikian penggalan surat Mugabe yang dibacakan juru bicara parlemen Jacob Mudenda. Mantan Wakil Presiden Emmerson Mnangagwa, yang sebelumnya dipecat oleh Mugabe, kemudian ditunjuk sebagai Presiden. Naiknya Mnangagwa memberikan banyak harapan kepada rakyat untuk menuju pelaksanaan demokrasi yang lebih baik di Zimbabwe. Namun di lain pihak, Mnangagwa sendiri adalah orang yang memiliki kedekatan khusus dengan militer, apalagi Mnangagwa mempunyai latar belakang militer. Bahkan muncul dugaan bahwa operasi militer yang terjadi sebenarnya disengaja untuk menyokong lahirnya rezim kepemimpinan Mnangagwa untuk melindungi kepentingan militer yang tidak dapat terpenuhi lagi di dalam rezim Mugabe. ${ }^{5}$

Hal ini kemudian menarik untuk dikaji terkait dinamika hubungan sipil militer yang berlangsung dalam perjalanan politik Zimbabwe. Eksistensi Mugabe ditopang oleh dukungan militer, namun dalam perjalanannya kekecewaan dalam tubuh institusi militer kemudian mendorong upaya pelengseran Mugabe sendiri. Lengsernya Mugabe selanjutnya melahirkan kepemimpinan baru yang juga tidak dapat dilepaskan dari posisi dan peran militer.

Beberapa penelitian telah mengkaji tentang hubungan sipil-militer di Zimbabwe era Mugabe. Williamsom, misalnya, mengkaji aspek struktural dan historis intervensi militer di Zimbabwe sekaligus menawarkan demonstrative model untuk

${ }^{4}$ Choirul Arifin, "Presiden Zimbabwe Robert Mugabe Mundur Setelah 37 Tahun Berkuasa," Tribun News, 22 November 2017, http://www.tribunnews.com/internasional/2017/1 1/22/presiden-zimbabwe-robert-mugabe-mundursetelah-37-tahun-berkuasa (diakses 3 Januari 2018).

${ }^{5}$ Yvonne Rowa, "After Mugabe: Why The Role of Zimbabwe's Army Can't Be Trusted?," The Conversation, 26 November 2017, https://theconversation.com/after-mugabe-whythe-role-of-zimbabwes-army-cant-be-trusted87872, (diakses 11 Desember 2017). mereformasi hubungan sipil-militer. ${ }^{6}$ Rupiya melihat hubungan sipil-militer di Zimbabwe sejak merdeka hingga Pemilu 2002 ketika institusi politik militer tampil sebagai suatu kekuatan politik utama. ${ }^{7}$ Adapun Bratton membahas tentang hubungan sipil-militer di Zimbabwe antara tahun 2008-2013 dan tantangan internal dalam mendorong terjadinya power-sharing di Zimbabwe. ${ }^{8}$ Penelitian lain seperti Chisaira, ${ }^{9}$ Southall, ${ }^{10}$ dan International Crisis Group ${ }^{11}$ membahas militerisme di Zimbabwe dan keberlanjutan dominasi militer pasca lengsernya Mugabe. Adapun tulisan ini memiliki batasan rentang waktu yang cukup panjang yakni berusaha mengurai dinamika hubungan sipil-militer yang berlangsung sejak perjuangan kemerdekaan, era kemerdekaan, kekuasaan Mugabe hingga perpecahan antara militer dan rezim yang ditandai dengan lengsernya Mugabe dan lahirnya pemerintahan baru.

${ }^{6}$ Jeremiah I. Williamson, "Seeking Civilian Control: Rule of Law, Democracy, and CivilMilitary Relations in Zimbabwe," Indiana Journal of Global Legal Studies: Vol. 17: Issue. 2, Summer: 2010, 389-411.

${ }^{7}$ Maryin R. Rupiya, "Civil-Military Relation in Zimbabwe: Is There a Threat?, https://oldsite.issafrica.org/uploads/OURSELVES RUPIYA.PDF (diakses 11 Desember 2017).

8 Michale Bratton, "Institutional Obstacles to Power-Sharing in Zimbabwe: Civilian-Military Relations, 2008-2013," Paper prepared for presentation on a panel on "Institutional Designs and Innovations in Power Sharing" at the 23rd IPSA World Congress, Montreal, Canada, July 19-24, 2014.

9 Lenin Tinashe Chisaira, "Zimbabwe's November 2017 Military Action: A Critique on Constitutionalism, Liberation Armies and Political Realities," November 2017, https://www.researchgate.net/publication/321278 208, (diakses 11 Desember 2018).

${ }^{10}$ Roger Southall, "Bob's Out, the Croc Is In: Continuity or Change in Zimbabwe?," Africa Spectrum, 52, 3/2017, 81-94.

${ }^{11}$ International Crisis Group, "Zimbabwe's "Military-assisted Transition and Prospects for Recovery," Crisis Group Africa Briefing $\mathrm{N}^{\circ} 134$, 20 December 2017. 
Najmuddin Khairur Rijal, Siti Malikatul Mushowwiroh | Dinamika Hubungan Sipil-Militer di Zimbabwe: dari Pra-Merdeka hingga Lengsernya Robert Mugabe

\section{Metode Penelitian}

Penelitian ini menggunakan metode deskriptif-kualitatif untuk menggambarkan permasalahan penelitian yang mengacu pada penyampaian fakta-fakta yang berhubungan dengan fokus penelitian tersebut. ${ }^{12}$ Teknik pengumpulan data dilakukan melalui studi dokumentasi (library research), di mana datadata dikumpulkan melalui berbagai sumber tertulis, seperti buku, jurnal, artikel online, dan website resmi.

\section{Tinjauan Pustaka: Hubungan Sipil-Militer}

Fokus tulisan ini adalah tentang hubungan sipil-militer. Kajian tentang hubungan sipil-militer identik dengan politik dan pemerintahan di negara-negara berkembang, terutama di negara yang dipimpin oleh pemerintahan yang otoriter seperti Zimbabwe. Secara konseptual, hubungan sipil-militer merujuk pada luasnya interaksi antara kekuatan bersenjata (militer) sebagai institusi dengan berbagai sektor masyarakat (sipil). Hubungan ini fokus pada adanya distribusi dan pemisahan kekuasaan antara pemerintah (sipil) dengan militer dalam suatu negara. ${ }^{13}$

Menurut Huntington, hubungan sipilmiliter dapat dilihat dari dua model, yaitu subjective civilian control dan objective civilian control. ${ }^{14}$ Subjective civilian control, yakni hubungan sipil-militer yang memaksimalkan kekuasaan sipil dan meminimalkan kekuasaan militer. Objective civilian control, yakni hubungan sipil-militer yang memaksimalkan profesionalisme militer dan menunjukkan adanya pembagian kekuasaan politik antara kelompok militer dan kelompok sipil yang kondusif menuju

12 Ulber Silalahi, Metode Penelitian Sosial (Bandung: PT. Refika Aditama, 2012), 28.

${ }^{13}$ Johanna Mendelson Forman and Claude Welch, Civil-Military Relations: USAID'S Role, (Washington: Center for Democracy and Governance Bureau for Global Programs, Field Support, and Research U.S. Agency for International Development, 2008), 7-8.

14 Samuel P. Huntington, The Soldier and The State: The Theory and Politics of Civil-Military Relations (Massachusetts: Harvard University Press, 1957), 80. perilaku profesional. Hubungan sipil-militer menjadi subjektif ketika salah satu dari sejumlah kekuatan yang berkompetisi dalam masyarakat berhasil mengontrol militer dan menggunakannya untuk tujuan dan kepentingan politik. Sementara, hubungan yang objektif mengandung adanya profesionalisme militer yang tinggi sesuai bidangnya sehingga meminimalisasi intervensi militer dalam politik dan minimalisasi intervensi politik dalam militer.

Terkait profesionalisme militer, Amos Perlmutter membagi profesionalisme militer menjadi dua, yakni profesionalisme personel dan profesionalisme korps. ${ }^{15}$ Profesionalisme personel meliputi keahlian, tanggung jawab dan kesatuan korps, yang didukung adanya sifat ulet, tekun, tegar, patuh, tulus, disiplin, dan menyenangi profesinya. Sedangkan profesionalisme korps meliputi adanya spesialisasi peran, yang didukung satu sumber otoritas kekuasaan. Antara keduanya memiliki hubungan yang saling mempengaruhi. Lebih lanjut, profesionalisme militer memiliki tiga ciri. ${ }^{16}$ Pertama yakni expertise (keahlian), yaitu adanya pengetahuan dan keahlian dalam bidang perang. Kedua adalah responsibility (tanggung jawab), di mana loyalitas militer hanya kepada negara tanpa preferensi kepada siapa pun. Ketiga, corporateness (karakter korporasi), yaitu memiliki semangat kesatuan dan sejalan dengan doktrini institusi militer. Apabila militer terlibat dalam politik, maka ia disebut tidak profesional dan hal itu dipandang telah terjadi apa yang disebut sebagai pembusukan politik (political decay).

Lebih lanjut, keterlibatan militer dalam politik ini disebut dengan istilah pretorianisme. Proterionsime mengacu pada situasi dimana militer tampil sebagai aktor politik utama yang dominan dan secara langsung menggunakan kekuasaan atau mengancam dengan menggunakan kekuasaan

15 Dalam Peter Britton, Profesionalisme dan Ideologi Militer Indonesia (Jakarta: LP3ES, 1996), 11-36.

16 Samuel P. Huntington, The Soldier and The State, 8-10. Lihat juga dalam Muhadjir Effendy, Profesionalisme Militer: Profesionalisasi TNI (Malang: UMM Press, 2008). 
mereka. ${ }^{17}$ Secara sederhana, pretorianisme merupakan campur tangan atau keterlibatan militer dalam politik. Selanjutnya, dalam tulisan ini, istilah atau konsep pretorianisme digunakan untuk menunjukkan keterlibatan militer dalam politik yang selanjutnya mempengaruhi pola hubungan sipil-militer yang terbentuk dalam perjalanan sejarah politik Zimbabwe.

\section{Hasil dan Pembahasan \\ Eksistensi Militer di Era Pra \\ Kemerdekaan (1960-1980)}

Pengakuan kemerdekaan atau pembebasan Zimbabwe dari kolonial Inggris pada 18 April 1980 menjadi titik awal untuk melihat eksistensi militer dalam politik Zimbabwe. Hal ini disebabkan karena pemerintah Zimbabwe maupun institusi militer sendiri baru secara resmi didirikan dan diakui paska kemerdekaan negara tersebut. Tetapi, peran militer Zimbabwe sebenarnya telah terlihat bahkan sebelum kemerdekaan, tepatnya di mana Zimbabwe masih berada di bawah pengaruh otoritas Inggris.

Saat itu militer merupakan pendukung utama gerakan sipil oleh orang-orang kulit hitam yang berencana untuk mengubah sistem politik Rodhesia (nama Zimbabwe saat masih menjadi bagian kekuasaan Inggris) menuju kepada sistem yang lebih independen. Untuk merealisasikan hal tersebut, terdapat dua kelompok ternama yang dibentuk oleh gerakan sipil yaitu Zimbabwe African National Union (ZANU) yang dipimpin oleh Robert Mugabe dan Zimbabwe African People's Union (ZAPU) di bawah pimpinan Joshua Nkmo. Masing-masing dari kelompok ini memiliki sayap militer yang berbeda dengan sebutan Zimbabwe African National Liberation Army (ZANLA) yang mendukung kelompok ZANU serta Zimbabwe People's Revolutionary Army (ZIPRA) yang mendukung kelompok ZAPU.

Pada beberapa perang gerilya, ZANLA dan ZIPRA berada pada satu garis aliansi untuk melawan tentara Rodhesia. Namun pada peperangan skala besar yang

17 Eric A. Nordlinger, Militer dalam Politik, Kudeta dan Pemerintahan (Jakarta: Rineka Cipta, 1990), 6. disebut dengan Perang Belukar Rodhesia atau Rodhesian Bush War dalam skema perang saudara pada tahun 1960-an, baik ZANLA maupun ZIPRA tidak saling mendukung yang kemudian menyebabkan wilayah Rodhesia berada dalam situasi darurat militer. Kelompok sipil yang terpecah juga mengakibatkan tidak adanya kepastian damai di wilayah tersebut, hingga akhirnya Inggris memutuskan untuk menjembatani negosiasi perdamaian yang berujung kepada kesepakatan penghentian perang dan pelaksanaan pemilihan umum untuk kelompok sipil Rodhesia di tahun 1980.

Dalam hal ini, kemenangan diraih oleh Robert Mugabe sebagai Perdana Menteri baru Rodhesia sekaligus menjadi sebuah simbol kemerdekaan. Pasca pemilu ini dilaksanakan barulah Inggris dan beberapa negara lainnya bersedia mengakui Rodhesia sebagai negara yang merdeka, yang kemudian diikuti dengan berubahnya identitas negara. Rodhesia berganti nama menjadi Zimbabwe dengan ibu kota Harare yang kemudian dikenal hingga saat ini.

\section{Posisi dan Peran Militer Pasca \\ Kemerdekaan (1980-1990)}

Setelah merdeka, Zimbabwe menerapkan sistem pemerintahan parlementer di bawah rezim Mugabe. Birokrasi dan institusi negara ditata untuk memberikan pelayanan bagi masyarakat. Tidak terkecuali pada institusi militer, ZANLA, ZAPRI, maupun mantan tentara Rhodesia diintegrasikan dalam Zimbabwe National Army (ZNA) dan dirangkul bersama Angkatan Udara Zimbabwe (Air Force Zimbabwe/ AFZ) di bawah satuan gabungan institusi pertahanan Zimbabwe yaitu Zimbabwe Defence Force (ZDF). ${ }^{18}$

ZDF secara keseluruhan ditujukan untuk melindungi negara sesuai dengan prioritas utama profesionalismenya. Tetapi secara spesifik, militer juga diarahkan kepada sebuah doktrin militer berdasarkan konstitusi Zimbabwe yang memuat fungsi-fungsi utama militer seperti: (a) Mempertahankan kemerdekaan, kedaulatan, dan integritas teritorial, serta kepentingan nasional

18 Jeremiah I.Williamson, "Seeking Civilian Control," 391. 
Najmuddin Khairur Rijal, Siti Malikatul Mushowwiroh | Dinamika Hubungan Sipil-Militer di Zimbabwe: dari Pra-Merdeka hingga Lengsernya Robert Mugabe

Zimbabwe, (b) Berpartisipasi dalam pembuatan arsitektur keamanan regional yang umum, (c) Berkontribusi pada pemeliharaan perdamaian dan stabilitas internasional, (d) Memberikan bantuan militer kepada otoritas sipil pada saat dibutuhkan. ${ }^{19}$

Dalam konteks ini, pemerintahan Mugabe mengarahkan militer pada profesionalismenya, terlihat dengan kerangka kerja yang mengerahkan dan mengalokasikan kekuatan militer tidak hanya berfokus untuk mengembangkan kapasitas berperang demi melindungi negara, tetapi juga menyediakan bantuan jasa di berbagai bidang kehidupan masyarakat dengan memberikan bantuan secara fisik maupun material. Di sisi lain, pasukan pertahanan Zimbabwe yang merupakan gabungan dua kekuatan Angkatan Udara (AZF) dan Angkatan Darat (ZNF) dalam fungsinya untuk memantau dan membela wilayah teritorial telah berhasil memberikan lingkungan yang kondusif untuk membangun ekonomi Zimbabwe.

Tindakan militer ini mengacu pada pemenuhan perannya yaitu Military Assistance to Civil Community (MACC) yang bersamaan dengan dua peran lainnya yaitu Military Assistance to Civil Ministries (MACM) dan Military Assitance to Civil Authorities (MACA). ${ }^{20}$ Agenda kerja militer ini secara keseluruhan dilaksanakan di bawah mandat Mugabe yang didukung dengan implementasi yang nyata dari pihak militer. Dalam kaitannya dengan ini, tampak bahwa militer menjalankan profesionalismenya di awal pemerintahan Mugabe. Hal ini setidaknya menunjukkan terbentuknya relasi sipil-militer yang objektif di mana institusi militer menjalankan tugas, fungsi, dan perannya sesuai dengan profesionalisme yang ada.

Tetapi, dalam perjalanannya, gejolak politik yang terjadi di Zimbabwe beberapa tahun setelah merdeka menjadi salah satu

19 "Zimbabwe Military-Doctrine, https://www.globalsecurity.org/military/world/afri ca/zw-doctrine.htm, (diakses 25 Desember 2017).

20 "Zimbabwean Soldiers in Peacetime," Chronicle News, 11 Agustus 2015, http://www.chronicle.co.zw/zimbabwean-

soldiers-in-peacetime/ (diakses 11 Desember 2017). penyebab ketidakstabilan negara. Permasalahan utama yaitu persaingan dan perebutan kekuasaan oleh kelompok ZANU dan ZAPU yang berkembang menjadi dua partai politik besar di Zimbabwe. Selain berlatar belakang karena konflik etnis antara etnis Ndebele (ZAPU) yang melawan adanya hegemoni kekuasaan oleh orang-orang yang ditunjuk Mugabe dari etnis Shona (ZANU). Mugabe juga menuntut adanya penyerahan hak prerogatif partai ZAPU kepada pemerintah yang ditolak keras oleh pihak ZAPU sehingga menyebabkan lahirnya konflik yang berujung pada sebuah peristiwa Pembantaian Gukurahundi.

Pembantaian Gukurahundi sendiri merupakan teror politik yang disponsori oleh Mugabe pada tahun 1983 dengan melibatkan kekuatan militer yang diarahkan untuk melakukan intimidasi, kekerasan, bahkan pembunuhan. Sasarannya adalah para pendukung partai ZAPU yang dianggap sebagai pembangkang karena memilih untuk menjadi oposisi dan tidak menuruti tuntutan pemerintah. Peristiwa ini menyebabkan sekitar 8.000 orang terbunuh dalam kurun waktu tiga tahun sejak dimulainya peristiwa tersebut. $^{21}$

\begin{tabular}{l}
\multicolumn{3}{c}{ Pembantaian Gukurahundi ini } \\
berakhir di tahun 1987 dengan \\
penandatanganan \\
mempersatukan partai ZANU dan ZAPU di \\
bawah Zimbabwe African National
\end{tabular} Patriotic Front (ZANU-PF) yang berkembang menjadi partai politik dengan otoritas terbesar di Zimbabwe. Terjadinya peristiwa pembantaian ini sekaligus menandai titik awal terjadinya maksimalisasi kekuatan militer untuk melindungi sebuah kepentingan pihak tertentu, khususnya kepentingan politik Mugabe. Hal ini sekaligus menunjukkan terjadinya kontrol yang subjektif atas militer dari yang sebelumnya objektif.

Pelibatan kekuatan militer dalam urusan politik Zimbabwe tidak berhenti sampai di situ. Beberapa peristiwa dalam skema kontrol subjektif terhadap militer dilakukan oleh Mugabe menjadi sebuah kultur politik yang dipraktikkan secara berkelanjutan. Kontrol subjektif ini menjadi

21 Jeremiah I.Williamson, "Seeking Civilian Control," 392. 
tidak terelakkan karena, menurut Williamson, adanya dukungan regulasi dalam konstitusi Zimbabwe yang mengatur tentang bagaimana konstitusi menempatkan presiden sebagai panglima tertinggi pasukan pertahanan yang memiliki kekuatan untuk menyatakan perang atau berdamai, serta menentukan penggunaan operasional pasukan pertahanan. ${ }^{22}$

Selain itu, dengan adanya prinsip bahwa militer juga harus memenuhi perannya dalam Military Assitance to Civil Authorities (MACA) yang secara tidak langsung harus mendukung keputusan pemerintah maka halhal tersebutlah yang kemudian menjadikan posisi Mugabe semakin diperkuat untuk dapat mengoperasikan militer sesuai dengan kepentingan politiknya. Pada kenyataannya, proses implementasi konstitusi maupun prinsip militer sering kali disalahgunakan, sehingga secara tidak langsung berdampak pada hubungan sipil-militer yang menghasilkan pretorianisme yang memberikan peluang intervensi militer dengan lebih jauh dalam urusan politik negara.

\section{Hubungan Sipil-Militer Era 1990-2017}

Tahun 1990, pemilihan umum Presiden pertama kali dilaksanakan setelah perubahan konstitusi negara yang dilakukan oleh Mugabe pada tahun 1987 untuk menciptakan sistem pemerintahan presidensial. ${ }^{23}$ Pemilu ini kiranya dipandang sebagai awal keberlangsungan demokratisasi di Zimbabwe. Pemilu dipastikan akan dilaksanakan setiap lima tahun sekali. Tapi dengan syarat bahwa Mugabe dapat mencalonkan diri untuk waktu yang tidak terbatas. Pemilu yang menjadi indikator demokrasi elektoral atau demokrasi prosedural yang berlangsung di Zimbabwe ini membawa Mugabe untuk memenangkan pemilu sekaligus berkuasa selama lima kali masa jabatan: tahun 1990, 1996, 2002, 2008, dan 2013. Tetapi, hasilnya tidak terlepas dari kritik dan kecaman dari masyarakat

\footnotetext{
22 Jeremiah I.Williamson, "Seeking Civilian Control," 399.

23 "Keterangan Dasar Negara Republik Zimbabwe,"

https://www.kemlu.go.id/harare/id/Pages/Zimbab we.aspx. (diakses 11 Desember 2017).
}

internasional yang melihat adanya politisasi militer untuk melindungi rezim berkuasa.

Hal tersebut diperjelas dengan peristiwa yang terjadi beberapa bulan menjelang pemilu di tahun 2002. Militer secara eksklusif memproklamasikan dirinya bahwa mereka tidak akan mendukung kepresidenan yang tidak berpartisipasi dalam upaya perang kemerdekaan. Hal ini dilakukan seiring terbentuk dan berkembangnya partai politik Movement for Democratic Change (MDC) yang dipimpin oleh Morgan Tsvangirai di tahun 1999. MDC memiliki pengaruh yang cukup luas untuk dapat mengambil suara rakyat dalam beberapa agenda demokrasi yang menjadi prioritas utamanya. Eksistensi MDC sekaligus menjadi ancaman bagi Mugabe dan partai politiknya yang pada saat itu mengalami social distrust akibat intervensi militer setelah sebelumnya sempat netral dan apolitis akibat tuntutan masyarakat sipil di akhir tahun $1999 .^{24}$ Bahkan posisi militer cukup dominan, di mana secara sepihak militer menyatakan berhak untuk menetapkan kriteria bagi orangorang yang dapat menjadi kandidat presiden. Sejak saat itu, militer militer bahkan mengancam untuk memveto setiap hasil pemilu yang bertentangan dengan kandidat pilihannya. $^{25}$

Akhirnya, Mugabe kembali memenangkan pemilihan presiden tahun 2002 untuk masa jabatan ketiga. Hal ini memicu perdebatan, mengingat pernyataan militer yang berjanji untuk menyokong kandidat Presiden tertentu yang sesuai dengan kriteria pilihannya. Kemenangan Presiden Mugabe dianggap tidak adil karena keberpihakan militer. Bahkan militer sendiri membenarkan bahwa militer menolak kepemimpinan di bawah partai MDC dan tidak akan menerima pemimpin tanpa keterlibatan dalam perang kemerdekaan. Selain itu, kepemimpinan MDC juga dianggap berbahaya sebab akan

\footnotetext{
${ }^{24}$ Martin R Rupiya, "Civil-Military Relations in Zimbabwe."

${ }^{25}$ Elias Mambo, "Army Must Stay Away From Politics," Zimbabwe Independent, 9 Oktober 2015 ,

https://www.theindependent.co.zw/2015/10/09/ar my-must-stay-away-from-politics/ (diakses 11 Desember 2017).
} 
Najmuddin Khairur Rijal, Siti Malikatul Mushowwiroh | Dinamika Hubungan Sipil-Militer di Zimbabwe: dari Pra-Merdeka hingga Lengsernya Robert Mugabe

berpotensi untuk mengembalikan kolonialisme di Zimbabwe dengan asumsi bahwa MDC merupakan bagian dari sekutu yang akan menjadi boneka Inggris untuk menjalankan pemerintahan di Zimbabwe. ${ }^{26}$

Namun demikian, dalam pemilu tahun 2008, MDC justru mampu meraih suara lebih banyak dari pada ZANU-PF. Suara Morgan Tsvangirai dalam pemilihan presiden unggul dengan $47.9 \%$ suara dibanding Robert Mugabe hanya mendapatkan $43.2 \%$ suara. $^{27}$ Akan tetapi, hal ini tidak secara langsung mengantarkan Tsvangirai untuk menduduki kursi kepresidenan. Hasil pemilu ternyata ditangguhkan karena alasan yang tidak jelas. Robert Mugabe yang dikabarkan siap untuk menyerahkan kursi kepresidenan ternyata tidak mendapat persetujuan dari pihak militer yang mendukungnya. Alasannya karena, militer sendiri mengetahui konsekuensi terhadap kekalahan Mugabe secara otomatis akan merugikan mereka. Militer memandang karakter dari kepemimpinan MDC sangat kontra terhadap militer sehingga memungkinkan mereka untuk dapat menuntut militer berdasarkan peristiwa pemilu sebelumnya.

Posisinya yang terancam akan kehilangan hak-hak istimewa (privileged) jika rezim Mugabe berakhir mendorong militer kemudian menyepakati kesepakatan dengan Mugabe untuk menjamin pemilihannya kembali. $^{28}$ Sebagaimana ketika Mugabe memberikan mandat pertama kali kepada militer untuk melakukan sebuah pembantaian terhadap para pendukung ZAPU yang dianggap membangkang terhadap pemerintah, hal yang sama juga dipraktekkan. Operasi militer dilakukan dengan aksi kekerasan, penyiksaan, pembantaian, bahkan pembunuhan yang ditargetkan kepada para pendukung partai MDC. Tindakan ini

26 "Presiden Zimbabwe Menuduh Inggris-AS Pembohong," Liputan 6, 3 Desember 2004, http://global.liputan6.com/read/91032/presidenzimbabwe-menuduh-inggris-as-pembohong (diakses 11 Desember 2017).

$27 \quad$ "Zimbabwe-2008 Elections," https://www.globalsecurity.org/military/world/afri ca/zw-politics-2008.htm (diakses 11 Desember 2017)

28 Jeremiah I.Williamson, "Seeking Civilian Control," 397. dimaksudkan untuk memberikan tekanan kepada mereka agar tidak memberikan dukungan terhadap MDC di putaran kedua pemilu. Dalam kurun waktu beberapa bulan, jumlah korban tercatat kurang lebih 85 orang terbunuh, 1.300 orang disiksa, dan 35.000 lainnya kehilangan tempat tinggal setelah aksi pembakaran rumah yang dilakukan oleh pasukan militer. $^{29}$

Setelah kejadian ini, dan karena kekhawatiran terhadap pendukungnya, pemimpin partai MDC Morgan Tsvangirai mengumumkan untuk tidak mengikuti pemilihan tahap kedua, yang akhirnya mengantarkan kembali Mugabe dilantik untuk masa jabatan baru. Pada titik inilah, tampak pola hubungan sipil-militer yang lahir sangat subjektif dan militer menjadi institusi yang terlibat secara langsung dalam aktivitas politik bahkan dengan penggunaan kekerasan untuk kepentingan politik tertentu. Hal ini menunjukkan tidak sehatnya pola hubungan sipil-militer yang lahir di era pemerintahan Mugabe. Polarisasi hubungan sipil-militer yang seperti ini berlangsung selama bertahun tahun di Zimbabwe, dan sebagai akibatnya baik militer maupun rezim pemerintahan membentuk keadaan saling ketergantungan satu sama lain dalam sebuah sistem patronase yang mengakibatkan eskalasi konflik berbasis politisasi militer di Zimbabwe tidak kunjung reda.

Tetapi apa yang terjadi pada pemilihan umum di tahun 2013 tampak berbeda dengan proses pemilu di tahun-tahun sebelumnya. Meskipun Robert Mugabe kembali menjadi kandidat terpilih dengan suara yang jauh lebih besar dari Tsvangirai, namun hasil pemilihan ini tidak menimbulkan kontroversi, kehadiran militer untuk memboikot hasil pemilihan umum seperti pada pemilu-pemilu sebelumnya tidak ditemukan. Kekalahan MDC, menurut Tendi, ditafsirkan sebagai sebuah kesalahan fatal akibat kampanye yang tidak efektif sebelum pemilu karena menghadapi kendala finansial. Sementara di sisi lain, ZANU-PF mengalahkan MDC dengan cara yang adil,

\footnotetext{
${ }^{29}$ Jeremiah I.Williamson, "Seeking Civilian Control."
} 
Najmuddin Khairur Rijal, Siti Malikatul Mushowwiroh | Dinamika Hubungan Sipil-Militer di Zimbabwe: dari Pra-Merdeka hingga Lengsernya Robert Mugabe

yang menyebabkan rakyat jatuh cinta kembali pada partai ini. ${ }^{30}$

Lebih lanjut, tahun 2013 juga sekaligus menjadi tahun di mana amandemen dan pemberlakuan konstitusi tahun 2013 dilaksanakan. Perubahan konstitusi ini juga diarahkan untuk mengatur dan memperjelas kedudukan militer di dalam politik Zimbabwe. Penjelasan terhadap fungsi maupun tugas militer Zimbabwe diatur dalam Bagian 1 tentang General Provision (ayat 206-210) dan Bagian 2 tentang Defence Forces (ayat 211-218). ${ }^{31}$ Hal yang penting dalam konstitusi ini adalah adanya aturan tentang posisi militer yang harus apolitis dan tidak diperkenankan untuk memihak kepada kelompok tertentu. Militer dituntut untuk menghormati hak dan kebebasan fundamental semua orang.

Pada poin ini, konstitusi 2013 setidaknya menunjukkan tentang hubungan sipil-militer ke arah yang sehat sesuai dengan profesionalisme militer. Selain itu, konstitusi 2013 ini juga memperbaharui aturan mengenai masa jabatan presiden terpilih yang hanya diperbolehkan memimpin selama dua kali masa jabatan atau maksimal 10 tahun. Tetapi, tidak berlaku mundur untuk Presiden Mugabe sendiri. Dengan kata lain, Mugabe diperbolehkan untuk dipilih kembali untuk masa jabatan kedua dalam pemilu di tahun 2018.

\section{Militer dan Lengsernya Robert Mugabe}

Namun, apa yang terjadi di tahun 2017 menjadi titik balik bagi upaya menempatkan militer pada profesionalismenya. Alih-alih menjadi institusi yang profesional, dorongan untuk memperoleh kembali hak-hak istimewanya (privileged) mendorong intervensi politik militer. Intervensi ini diidentifikasikan

\footnotetext{
${ }^{30}$ Blessing-Miles Tendi, "Why Robert Mugabe Scored a Landslide Victory In Zimbabwean Election," The Guardian, 5 Agustus 2013, https://www.theguardian.com/world/2013/aug/05/ robert-mugabe-zimbabwe-election-zanu-pf, (diakses 11 Desember 2017).

31 "Constitution of Zimbabwe Amendment (NO 20),"

http://www.parlzim.gov.zw/component/k2/downl oad/1290_da9279a81557040d47c3a2c27012f6e1 (diakses 27 Desember 2017).
}

sebagai sebuah upaya kudeta oleh berbagai pihak, termasuk masyarakat lokal dan dunia internasional. Aksi militer yang melakukan pengepungan terhadap kediaman presiden, para pejabat dan menteri, jalanan umum, bahkan media massa menjadi indikasi upaya kudeta. Meskipun begitu, militer yang menolak operasinya dikatakan sebagai sebuah kudeta, lebih memilih untuk menyebutnya sebagai sebuah tindakan untuk menangkap "penjahat" di sekitar presiden yang dianggap sebagai akar permasalahan yang telah banyak menyebabkan penderitaan sosial dan krisis ekonomi berkepanjangan di Zimbabwe. ${ }^{32}$

Tindakan yang dilakukan oleh militer ini mengindikasikan tidak harmonisnya hubungan antara militer dan Mugabe. Tindakan tersebut dapat dilihat sebagai usaha untuk meninggalkan rezim Mugabe yang selama ini ditopangnya. Tidak hanya itu, tindakan militer dapat pula ditafsirkan memiliki motif yang lebih besar dari pada sekedar menggantikan pemimpin. Sebab, krisis suksesi terjadi di Zimbabwe, di mana memunculkan perdebatan tentang siapa yang akan menggantikan kekuasaan Mugabe. Krisis suksesi ini memicu persaingan dalam internal partai ZANU-PF sebagai partai yang berkuasa, terutama karena Mugabe lebih mempersiapkan istrinya Grace dalam suksesi.

Fakta menunjukkan bahwa setelah Robert Mugabe secara resmi mengundurkan diri pada 22 November 2017, Emmerson Mnangagwa yang sebelumnya dipecat Mugabe sebagai Wakil Presiden untuk memuluskan langkah Grace, kemudian ditunjuk sebagai Presiden. Naiknya Mnangagwa memunculkan optimisme tentang demokratisasi di Zimbabwe. Tetapi, di lain pihak, Mnangagwa sendiri adalah orang yang memiliki kedekatan khusus dengan militer, apalagi Mnangagwa mempunyai latar belakang militer. Bahkan muncul dugaan bahwa operasi militer yang terjadi sebenarnya disengaja untuk menyokong lahirnya rezim kepemimpinan Mnangagwa untuk melindungi kepentingan militer yang tidak dapat terpenuhi lagi di dalam rezim Mugabe. ${ }^{33}$

\footnotetext{
${ }^{32}$ Adam Taylor, "Zimbabwe : When A Coup".

${ }^{33}$ Yvonne Rowa, "After Mugabe."
} 
Najmuddin Khairur Rijal, Siti Malikatul Mushowwiroh | Dinamika Hubungan Sipil-Militer di Zimbabwe: dari Pra-Merdeka hingga Lengsernya Robert Mugabe

Mnangagwa merupakan anggota partai ZANU-PF dari etnis Ndebele. Militer berada dalam barisan pihak yang mendukung kepemimpinan Mnangagwa. Dalam hal ini, Mnangagwa sendiri yang dalam catatan reputasi militernya, merupakan salah satu personil utama yang diandalkan untuk melancarkan beberapa operasi militer yang digunakan untuk mencapai kepentingan politik. Misalnya pada operasi militer di tahun 1983-1987 tepatnya dalam Pembantaian Gukurahundi, Mnangagwa juga turut terlibat sebagai bagian dari militer yang melakukan pembantaian terhadap para pendukung partai ZAPU pada waktu itu. Meskipun Mnangagwa sendiri sempat tidak menyetui keterlibatannya, namun beberapa laporan dari surat kabar yang dikelola oleh negara menginformasikan bahwa Mnangagwa turut mendukung aksi tersebut. ${ }^{34}$

Selain itu, Mnangagwa juga dikabarkan menjadi aktor utama yang memberikan kontribusi ide dalam menggencarkan kampanye kekerasan politik di tahun 2008 untuk mengantisipasi kekalahan Mugabe dari Morgan Tsvangirai dalam pemilihan umum di putaran pertama. Suksesnya operasi militer untuk menghapuskan kubu oposisi terkuat tersebut yang mengantarkan Mugabe ke kursi kepresidenan untuk keempat kalinya kemudian menjadi catatan prestasi Mnangagwa. Hal ini kemudian diapresiasi dengan pengangkatannya sebagai wakil presiden pada tahun 2014. Artinya, posisi Mnangagwa sebagai wakil presiden perlu dibaca sebagai representasi kepentingan militer di pemerintahan. Sehingga, pemecatannya sebagai wakil presiden memicu polemik dalam institusi militer yang selanjutnya mendorong upaya kudeta terhadap Mugabe.

Karena itu, kursi presiden yang diduduki Mnangagwa diprediksikan sebagai bentuk dan hasil konspirasinya dengan militer

34 Andrew Simmons, "Zimbabwe: Victims Of Mass 1980s Killings Still Wait For Justice," AlJazeera, 11 Desember 2017, http://www.aljazeera.com/news/2017/12/zimbabw es-president-implicated-1980s-massacres-

171210133044991.html, (diakses 15 Desember 2017). untuk menurunkan rezim Mugabe. Peristiwa pemecatannya dilihat sebagai sebuah penghinaan terhadap harga diri militer, terlebih dengan pencalonan Greece Mugabe sebagai calon suksesor. Mnagagwa sendiri juga merupakan orang ambisius yang dinilai haus akan kekuasaan. Asumsi ini didukung dengan adanya pernyataan dari Mnangagwa sendiri yang disampaikan melalui beberapa media beberapa hari setelah pemecatannya, yang mengatakan bahwa ia menyayangkan tindakan Presiden Mugabe yang dianggap tidak benar untuk memasukkan dirinya sebagai salah satu kubu oposisi yang harus dibersihkan dalam rangka meneruskan suksesi kepemimpinan yang ditujukan untuk keluarganya. Kekecewaannya itu ditunjukkan ketika mengumumkan pada rakyat Zimbabwe, bahwa suatu saat nanti ia akan kembali ke Zimbabwe sebagai seorang pemimpin yang akan memberikan kesejahteraan kepada rakyatnya. ${ }^{35}$ Pada akhirnya, pernyataannya tersebut benar-benar dibuktikan, di mana selang beberapa hari setelah pemecatannya, diikuti dengan upaya kudeta yang akhirnya menempatkan Mnagagwa sebagai presiden, setelah sempat melakukan pengasingan diri di luar negeri.

\section{Kesimpulan}

Uraian dalam tulisan ini menunjukkan bahwa akar historis pola relasi hubungan sipil-militer dalam politik telah dimulai sejak perjuangan kemerdekaan. Kemerdekaan Zimbabwe selanjutnya mengantar Robert Mugabe sebagai presiden. Awal pemerintahan Mugabe menempatkan militer pada profesionalismenya. Namun, dalam perjalanannya, militer digunakan sebagai alat politik untuk mempertahankan kekuasaan Mugabe sehingga menjadikan pola hubungan sipil-militer menjadi kontrol subjektif.

Selanjutnya, amandemen konstitusi pada tahun 2013 menandai upaya menempatkan militer sesuai dengan profesionalismenya. Konstitusi menuntut militer untuk apolitis. Namun, faktanya,

\footnotetext{
${ }^{35}$ Lebo Diseko, "Emmerson Mnangagwa : Will He Be Different From Mugabe?," BBC News, 24 November 2017 , http://www.bbc.com/news/world-africa-42073481 (diakses 11 Desember 2017).
} 
Najmuddin Khairur Rijal, Siti Malikatul Mushowwiroh | Dinamika Hubungan Sipil-Militer di Zimbabwe: dari Pra-Merdeka hingga Lengsernya Robert Mugabe

upaya untuk melanggengkan dominasi kekuasaan Mugabe menjadikan militer menyokong keberlanjutan rezim. Hal ini tidak terlepas dari hak-hak istimewa yang dimiliki oleh militer. Namun, upaya Mugabe untuk mewariskan kekuasaan kepada istrinya dan memecat wakil presiden Mnangagwa dipandang sebagai ancaman bagi kepentingan pihak militer. Karenanya, dukungan militer terhadap Mugabe berbalik arah yang ditandai dengan upaya kudeta.

Tindakan militer ini dipandang sebagai skenario untuk menjadikan Mnangagwa sebagai presiden yang dinilai dapat menjaga kepentingan militer. Hal ini menunjukkan dinamika pasang surut hubungan sipil-militer dalam politik Zimbabwe dari kontrol objektif menjadi kontrol subjektif, kemudian menjadi kontrol objektif hingga kembali kontrol subjektif sebelum akhirnya menanggalkan dukungannya pada Mugabe untuk tetap menjaga kepentingannya. Pada akhirnya, beralihnya dukungan militer atas Mugabe menandai berakhirnya kekuasaan Mugabe selama 37 tahun. Hal ini sejalan dengan penegasan Huntington, bahwa eksistensi kekuasaan otoriter sangat ditentukan oleh posisi militer. Namun kepemimpinan Mnangagwa, sebagaimana temuan Southall, mengindikasikan kelanjutan dari pemerintahan otoriter, alih-alih mendorong reformasi.

Implikasi tulisan ini mempertegas kembali bahwa hubungan sipil-militer dalam pemerintahan otoriter akan selalu bersifat kontrol subjektif karena pemerintahan otoriter ditopang oleh kekuatan militer. Kemudian, berakhirnya pemerintahan otoriter cenderung selalu diawali dengan penarikan dukungan oleh militer terhadap rezim. Namun, momentum berakhirnya era otoritarianisme akan menjadi peluang bagi militer untuk tetap kembali menjadi aktor politik utama ketika tampilnya pemerintahan yang baru difasilitasi oleh militer. 
Najmuddin Khairur Rijal, Siti Malikatul Mushowwiroh | Dinamika Hubungan Sipil-Militer di Zimbabwe: dari Pra-Merdeka hingga Lengsernya Robert Mugabe

\section{DAFTAR PUSTAKA}

\section{Buku}

Britton, Peter. Profesionalisme dan Ideologi Militer Indonesia. Jakarta: LP3ES, 1996.

Effendy, Muhadjir. Profesionalisme Militer: Profesionalisasi TNI. Malang: UMM Press, 2008.

Forman, Johanna Mendelson dan Claude Welch. Civil-Military Relations: USAID'S Role. Washington:

Center for Democracy and Governance Bureau for Global Programs, Field Support, and

Research U.S. Agency for International Development, 2008.

Huntington, Samuel P. The Soldier and The State: The Theory and Politics of Civil-Military Relations. Massachusetts: Harvard University Press, 1957.

Huntington, Samuel P. Gelombang Demokratisasi Ketiga. Jakarta: Pustaka Utama Grafiti, 1995.

Nordlinger, Eric A. Militer dalam Politik, Kudeta dan Pemerintahan. Jakarta: Rineka Cipta, 1990.

Silalahi, Ulber. Metode Penelitian Sosial. Bandung: PT. Refika Aditama, 2012.

\section{Jurnal dan Artikel Penelitian}

Bratton, Michael. "Institutional Obstacles to Power-Sharing in Zimbabwe: Civilian-Military Relations, 2008-2013." Paper prepared for presentation on a panel on "Institutional Designs and Innovations in Power Sharing" at the 23rd IPSA World Congress, Montreal, Canada, July 19-24, 2014.

Chisaira, Lenin Tinashe. "Zimbabwe's November 2017 Military Action: A Critique on Constitutionalism, Liberation Armies and Political Realities." November 2017, https://www.researchgate.net/publication/321278208, (diakses 11 Desember 2018).

International Crisis Group, "Zimbabwe's "Military-assisted Transition and Prospects for Recovery." Crisis Group Africa Briefing N¹34, 20 December 2017.

Williamson, Jeremiah I. "Seeking Civilian Control: Rule of Law, Democracy, and Civil - Military Relations in Zimbabwe." Indiana Journal of Global Legal Studies, Volume 17, No. 2, Summer 2010: 389-410.

Southall, Roger. "Bob's Out, the Croc Is In: Continuity or Change in Zimbabwe?." Africa Spectrum, 52, 3/2017, 81-94.

\section{Artikel Online}

Arifin, Choirul. "Presiden Zimbabwe Robert Mugabe Mundur Setelah 37 Tahun Berkuasa." Tribun News, 22 November 2017. http://www.tribunnews.com/internasional/2017/11/22/presidenzimbabwe-robert-mugabe-mundur-setelah-37-tahun-berkuasa (diakses 3 Januari 2018).

Diseko, Lebo. "Emmerson Mnangagwa : Will He Be Different From Mugabe?" BBC News, 24 November 2017. http://www.bbc.com/news/world-africa-42073481 (diakses 11 Desember 2017).

Mambo, Elias. "Army Must Stay Away From Politics.” Zimbabwe Independent, 9 Oktober 2015. https://www.theindependent.co.zw/2015/10/09/army-must-stay-away-from-politics/ (diakses 11 Desember 2017).

Maringira, Godfrey dan Tyanai Masiya. "Implications of a Politicised Military." Zimbabwe Independent, 11 Desember 2017. https://www.theindependent.co.zw/2017/12/11/implicationspoliticised-military/ (diakses 15 Desember 2017).

Rowa, Yvonne. "After Mugabe: Why The Role of Zimbabwe's Army Can't Be Trusted?" The Conversation, 26 November 2017. https://theconversation.com/after-mugabe-why-the-role-ofzimbabwes-army-cant-be-trusted-87872, (diakses 11 Desember 2017).

Rupiya, Martin R. "Civil-Military Relations in Zimbabwe Is There a Threat?" https://oldsite.issafrica.org/uploads/OURSELVESRUPIYA.PDF (diakses 11 Desember 2017).

Simmons, Andrew. "Zimbabwe: Victims Of Mass 1980s Killings Still Wait For Justice." Al- Jazeera, 11 Desember 2017. http://www.aljazeera.com/news/2017/12/zimbabwes-president-implicated1980s-massacres-171210133044991.html, (diakses 15 Desember 2017).

Taylor, Adam. "Zimbabwe: When A Coup Is Not A Coup?" The Washington Post. https://www.washingtonpost.com/news/worldviews/wp/2017/11/15/zimbabwe-when-a-coup-isnot-a-coup/?utm term=.c07cf8316f4a (diakses 12 Desember 2017). 
Najmuddin Khairur Rijal, Siti Malikatul Mushowwiroh | Dinamika Hubungan Sipil-Militer di Zimbabwe: dari Pra-Merdeka hingga Lengsernya Robert Mugabe

Tendi, Blessing-Miles. "Why Robert Mugabe Scored a Landslide Victory In Zimbabwean Election." The Guardian, 5 Agustus 2013. https://www.theguardian.com/world/2013/aug/05/robert-mugabezimbabwe-election-zanu-pf, (diakses 11 Desember 2017).

"Constitution of Zimbabwe Amendment (NO 20)." http://www.parlzim.gov.zw/component/k2/download/1290_da9279a81557040d47c3a2c27012f6e $\underline{1}$ (diakses 27 Desember 2017).

"Keterangan Dasar Negara Republik Zimbabwe." https://www.kemlu.go.id/harare/id/Pages/Zimbabwe.aspx. (diakses 11 Desember 2017).

"Presiden Zimbabwe Menuduh Inggris-AS Pembohong." Liputan 6, 3 Desember 2004. http://global.liputan6.com/read/91032/presiden-zimbabwe-menuduh-inggris-as-pembohong (diakses 11 Desember 2017).

“Zimbabwe Military-Doctrine.” https://www.globalsecurity.org/military/world/africa/zw-doctrine.htm (diakses 25 Desember 2017).

"Zimbabwean Soldiers in Peacetime." Chronicle News, 11 Agustus 2015. http://www.chronicle.co.zw/zimbabwean-soldiers-in-peacetime/ (diakses 11 Desember 2017)

“Zimbabwe-2008 Elections." https://www.globalsecurity.org/military/world/africa/zw-politics-

2008.htm (diakses 11 Desember 2017)

\section{Biodata Penulis}

Najamuddin Khairur Rijal adalah pengajar pada Program Studi (Prodi) Ilmu Hubungan Internasional (HI) Universitas Muhammadiyah Malang (UMM). Menyelesaikan jenjang S1 Prodi HI UMM pada tahun 2013. Kemudian, melanjutkan jenjang S2 pada Program Pascasarjana HI Universitas Airlangga Surabaya dan lulus pada tahun 2015. Memiliki ketertarikan pada kajian demokrasi dan civil society, globalisasi, terorisme, dan kajian kawasan Asia Tenggara. Dapat dihubungi melalui email najamuddin@umm.ac.id.

Siti Malikatul Mushowwiroh saat ini tercatat sebagai mahasiswa Program Studi (Prodi) Ilmu Hubungan Internasional (HI) Universitas Muhammadiyah Malang (UMM) angkatan 2015. Malika dapat dihubungi melalui malikhaarb@gmail.com. 